\title{
Urban Markström
}

\section{Stöd till personer med psykisk funktionsnedsättning}

- etablering av ett nytt verksamhetsfält

\begin{abstract}
Establishment of community mental health services in Sweden
Care and support for people with psychiatric disabilities has been subject to significant changes during recent decades. Institution-based forms of care have been replaced by policies focused on inclusion and participation in society, and by a new field of community-oriented services. The formal responsibility for supporting the target group has largely shifted from mental health care to municipal social services. This article characterizes this new field of expertise, and discusses a number of current themes that seem to influence the extent to which policy-level objectives can be achieved. One theme is the establishment of a knowledge base regarding community-based services, in which local development work and academic research have sometimes enriched each other. Individual support towards employment is used as one example of a model developed through a combination of service innovation and research. Another theme concerns the concept of personal recovery, which has contributed to a new ideological orientation, where the lived experience of service users and issues of participation and involvement are emphasized. Furthermore, the problem of in-real-life implementation is discussed. A significant share of the current knowledge on effective service and support is never implemented in real practice, neither at a national nor a local organizational level. This "treatment gap" should be considered as one of the primary challenges in community mental health services today. This article highlights a study where researchers sought to identify critical components for long-term establishment of evidence-based services. Finally, the field of community mental health services is portrayed as slowly establishing both organizational forms and a foundation of research- and experience-based knowledge.
\end{abstract}

Urban Markström är professor vid Institutionen för social arbete, Umeå universitet.

Kontakt: urban.markstrom@umu.se 


\section{5 år av reformarbete}

Det jubileumsnummer som den här artikeln ingår i markerar ett kvarts sekel av socialvetenskaplig forskning rapporterad på svenska. Tidsramen sammanfaller med några av de mest profilerade välfärdsreformerna i modern svensk historia. År 1994 trädde den så kallade handikappreformen i kraft, vilket innebar ett tydliggjort kommunalt ansvar för stöd till personer med funktionsnedsättning. Reformarbetets hårda kärna utgjordes av lagen (1993:387) om stöd och service till vissa funktionshindrade, LSS, som innehöll tio olika insatser och som syftade till att främja jämlikhet i levnadsvillkor och full delaktighet i samhällslivet för målgruppen. Året efter sjösattes psykiatrireformen som markerade en definitiv övergång från ett sjukhusbaserat till ett samhällsorienterat system för stöd till personer med långvarig psykisk sjukdom och funktionsnedsättning. Även här fick kommunerna ett förtydligat ansvar för sociala insatser till målgruppen, bland annat formaliserat genom justeringar i socialtjänstlagen (2001:453).

Hur har då de här reformerna påverkat synen på målgruppen och den professionella praktik som tillämpas inom välfärdssektorn? I den här texten kommer jag att identifiera och diskutera några utvecklingsområden - kunskapsbasering, personlig återhämtning, delaktighet i samhällslivet samt stöd till arbete och anställning. Områdena bildar ingen kongruent tematik utan har valts utifrån metoden att hålla "fingret i luften" och känna av aktuella strömningar i det samhällsbaserade arbetet med målgruppen. Kunskapsbasering avser en ökad uppmärksamhet på forskning och den så kallade evidensrörelsen. Återhämtning rör principer och perspektiv utvecklade ur brukarnas egna erfarenheter. Delaktighet är ett nyckelbegrepp på övergripande policynivå men betraktas ofta också som ett konkret mål i kunskaps- och återhämtningsbaserat arbete. Stöd till arbete är ett exempel på ett konkret insatsområde där både kunskapsutveckling och idéer om återhämtning flätats samman. Kännetecknande för dessa områden är att de direkt eller indirekt kan ha betydelse för målgruppens livssituation.

I artikeln kommer jag också att ägna uppmärksamhet åt frågan om lokal implementering, som utgör ett kritiskt steg mot att förverkliga reformeringsarbetets mål och intentioner. Nya arbetsmetoder med starkt vetenskapligt stöd liksom formulerade principer om återhämtning och delaktighet behöver "översättas" till de sammanhang där de ska praktiseras - något som har visat sig vara utmanande, framför allt när det handlar om komplexa arbetsmetoder eller verksamhetsområden där flera aktörer med olikartade uppdrag är involverade. Frågan om implementering har här adresserats av det enkla skälet att den har avgörande betydelse för hur väl verksamhetsfältet samhällsbaserat stöd kan etableras och utvecklas. De nämnda utvecklingsområdena relateras främst till den grupp av personer som har stora och långvariga konsekvenser av psykisk ohälsa - här benämnda personer med psykisk funktionsnedsättning. 


\section{Ett nytt verksamhetsfält tar form}

Förändringarna på psykiatriområdet har de senaste decennierna varit i högsta grad påtagliga. I ett svenskt perspektiv är den huvudsakliga rörelsen nedmonteringen av de stora mentalsjukhusen och en följande utveckling av verksamheter och insatser inom kommunernas organisation. Vårdplatserna inom psykiatrisk heldygnsvård har reducerats från över $35000 \mathrm{i}$ mitten av 1960-talet till att i dag ligga på cirka 3000 (Markström, 2003; Uppdrag psykisk hälsa, 2017). Samtidigt har kommunalt organiserade insatser byggts upp. Före psykiatrireformen fanns ett fåtal personer med psykisk funktionsnedsättning i anpassade boendeformer - fem år efter reformen var siffran över 8000 personer (Socialstyrelsen, 2003). I den fortsatta utvecklingen har tyngdpunkten förskjutits från gruppbostäder och så kallade servicebostäder till insatser i mer flexibla former där stödet ges i den enskildes egen bostad. Den formen av boendestöd erbjöds enligt den senaste inventeringen fler än 18000 personer (Socialstyrelsen, 2013a). Verksamheter för social samvaro och sysselsättning etablerades snabbt efter att reformen trätt i kraft och i dag erbjuder nio av tio svenska kommuner denna typ av insats (Socialstyrelsen, 2017a). Dock finns en kritisk diskussion både internationellt och i Sverige om den standardiserade och skyddade karaktär som präglar många av verksamheterna (Lindqvist, Markström \& Rosenberg, 2014). Som framgått är den övergripande bilden en tydlig reduktion av slutenvård och en samtidig expansion av stödinsatser utanför vårdinrättningarna. Förändringsarbetet har emellertid varierat i både tempo och omfattning, och kvalitetsskillnaderna mellan de svenska kommunerna har beskrivits som oacceptabelt stora (SOU 2006:100).

En annan generell förändring som kan identifieras i västvärlden rör föreställningarna om målgruppens möjligheter att bli delaktiga i samhället, till exempel på arbetsmarknaden, där pessimism och uppgivenhet, åtminstone på principnivå, ersatts av en mer optimistisk hållning (Bejerholm \& Roe, 2018; Leff \& Warner, 2006). I den meningen kan man hävda att samhället i dag i högre utsträckning adresserar och tar sig an de begränsningar som följer på funktionsnedsättningen i sig, negativa attityder i samhället samt de brister som kan finnas i välfärdssystemens utformning. Optimismen kontrasteras dock av besvärande fakta. Målgruppen har i Sverige en ökad dödlighet i somatiska och åtgärdbara sjukdomar jämfört med befolkningen i övrigt. Överlevnaden har de senaste decennierna ökat i den totala befolkningen men inte hos personer med en psykiatrisk diagnos, vilka som grupp har en betydligt kortare förväntad livslängd än andra (Socialstyrelsen, 2013b). Andra utmaningar är de missförhållanden kring samarbete och samordning av insatser mellan myndigheter som kan få stora konsekvenser för personer med samtidiga behov av både sociala och psykiatriska insatser.

I Sverige har psykiatriområdet stått i fokus för återkommande politiska initiativ. Med start i början av 1970-talet har ett pärlband av statliga utredningar producerats 
i relation till området, och sedan 1990-talet har statliga ekonomiska satsningar lanserats med regelbundenhet. Kortare nationella satsningar, präglade av en "projektlogik" (Jensen, Johansson \& Löfström, 2017), har i det närmaste staplats på varandra (Vårdanalys, 2015). Satsningarna har oftast riktats mot den grupp som har omfattande och långvariga behov av stöd (Bergmark, Bejerholm \& Markström, 2017; SOU 2018:90; Vårdanalys, 2015). Sedan några år tillbaka finns emellertid en internationell trend där en bredare och mer folkhälsoorienterad ansats vunnit utrymme på policynivå (Gureje, 2015; Metha, Croudace \& Davies, 2015; Wahlbeck, 2015). I Sverige kan detta illustreras genom de överenskommelser mellan regeringen och Sveriges Kommuner och Landsting (SKL) som slutits i relation till vad som kallats "Uppdrag psykisk hälsa" (Regeringskansliet \& SKL, 2016; SOU 2018:90) och genom den särskilda utredare och nationella samordnare som arbetat med frågorna mellan 2016 och 2018 (dir. 2016:106). I både policydokument och riktade satsningar har betoningen legat på en bredare målgrupp än tidigare och på förebyggande och tidiga insatser (SOU 2018:90). I de handlingsplaner som alla län i Sverige regelbundet sammanställde under perioden syns tydligt hur områden som barn och ungas psykiska hälsa samt insatser som suicidprevention och elevhälsovård prioriteras (Fjellfeldt, Rosenberg \& Markström, 2017; Fjellfeldt \& Markström, 2018). Vad konsekvenserna av den ansatsen blir för personer med långvarig funktionsnedsättning är ännu inte möjligt att uttala sig om. Ur handlingsplanerna går dock att utläsa att välfärdsaktörerna i hög utsträckning tycks applicera ett (sekundär- och tertiär) preventivt perspektiv även på den gruppen, vilket kan utgöra grund för nya synsätt och strategier (Fjellfeldt \& Markström, 2018). Emellertid kan ett utpräglat folkhälsoperspektiv även bidra till att utvecklingsarbete inom funktionshinderområdet nedprioriteras.

\section{Mot en större kunskapsbas}

Det omfattande arbetet att avinstitutionalisera som rört personer med psykisk funktionsnedsättning har inte genomförts utan problem. Bland de utmaningar som identifierats i delar av västvärlden finns bland annat låg tillgänglighet på insatser vid kriser, bristfällig samordning mellan berörda myndigheter, de-professionalisering av insatserna samt utveckling av nya institutionslika verksamheter med undermåligt rehabiliteringsinnehåll (Thornicroft et al., 2011). Problemen har framstått som särskilt påtagliga i de tidiga faserna av reformarbetet. Andra förhållanden har utvecklats i positiv riktning. Den mest påtagliga förändringen rör utan tvivel kunskapsutvecklingen av samhällsbaserade och psykosociala insatser, som kontinuerligt pågått sedan den konkreta nedmonteringen av mentalsjukhusen inleddes. I samband med den svenska psykiatrireformen fanns ett påfallande intresse av att identifiera best practices för insatser som boendestöd, sysselsättning, social färdighetsträning och integrerat stöd. Dock var referenspunkterna och förebilderna få vid den tidpunkten, vilket 
även enligt Bergmark och kollegor blir tydligt i statliga policydokument (Bergmark, Bejerholm \& Markström, 2017). Den vanliga strategin för svenska kommuner blev att arrangera studiebesök till andra kommuner för att utbyta idéer och få inspiration (Bergmark, 2018; Markström \& Lindqvist, 2015). Men internationellt hade en rörelse inletts i samband med avinstitutionaliseringen och som med tiden utvecklats till ett systematiskt arbete med att utforma, pröva och utvärdera olika arbetssätt inom ramen för det fält som benämns community mental health services (Thornicroft et al., 2011). Några decennier senare finns en förhållandevis bred kunskapsbas med en rad modeller som visar på goda resultat och som finns sammanställda i systematiska kunskapsöversikter eller i nationella riktlinjer (Socialstyrelsen, 2018; Bergmark, 2018). En del av modellerna är beskrivna i arbetsböcker eller i särskilda manualer för att kunna bedöma så kallad programtrohet. I dag, ett kvarts sekel efter startskottet för kommunaliseringen av psykiatrin, är situationen alltså potentiellt gynnsam, med en praktik som kan förhålla sig till en mångårig erfarenhet samt ett internationellt forskningsfält där man fortlöpande studerar och reviderar avinstitutionaliseringens första generation av insatser (Markström \& Lindqvist, 2015).

\section{Nya perspektiv}

Parallellt med att etablera en kunskapsbas har även synsätt och perspektiv inom området ändrat karaktär. Förändringarna drevs till en del på av politiska och vårdideologiska motiv, och målsättningar om ökad delaktighet och inkludering i samhället för personer med psykisk funktionsnedsättning formulerades tidigt. Emellertid har den senare idéutvecklingen utgjort en kombination av normativt drivna argument och principer nära knutna till aktuella forskningsresultat (Bejerholm \& Roe, 2018). Detta blir tydligt när det gäller konceptet personlig återhämtning (personal recovery). Med den termen vill förespråkarna rikta uppmärksamheten bort från deterministiska och pessimistiska föreställningar om psykisk sjukdom och en vård som fokuserat på symtomreduktion. I fokus står i stället principer som samhörighet, hopp, optimism, meningsfullhet, identitet och empowerment (Leamy et al., 2011). Ofta definieras personlig återhämtning som en pågående personlig process mot värderade sociala roller och ett meningsfullt liv, oaktat kvarvarande psykiatriska symtom (Leonhardt et al., 2017; Richardson \& Barkham, 2017). Hypotetiskt blir följderna av att använda ett sådant perspektiv att på ett annat sätt än tidigare lyssna på och värdera den enskildes egen levda erfarenhet, snarare än att utgå från de professionella eller verksamhetens premisser. Det skulle kunna medföra ökad uppmärksamhet på personliga och vardagsnära målsättningar i stödet, på bekostnad av fokuseringen på effekter av den medicinska behandlingen. 


\section{En väg mot ökad delaktighet?}

Principerna bakom konceptet går att spåra ur minst två traditioner. Den ena består i den forskning som växte $\mathrm{i}$ avinstitutionaliseringens spår och som intresserade sig för hur personer som vårdats på mentalsjukhus klarade sig utanför vårdinrättningarna. Här finns blandade resultat, men flera långtidsuppföljningar kunde visa på möjligheter för personer med psykiska funktionsnedsättningar att klara ett liv ute i samhället och att i många fall uppleva förbättrad hälsa och livskvalitet (Thomas et al., 2018). Den andra traditionen utgörs av samlade berättelser från personer med levd erfarenhet av svår psykisk ohälsa och deras röster om vägen tillbaka till ett fungerande liv. De har getts utrymme via brukarrörelsen och olika öppna forum, men även genom kvalitativa intervjustudier. Här finns bland annat tidiga svenska studier av Alain Topor och Ulla-Karin Schön (Topor, 2001; Schön, 2009). Ur denna "bekännelsetradition" har kunskap vuxit fram om bland annat värdet av att förmedla hopp och att utforma stöd utifrån den enskildes unika behov och erfarenheter (Onken et al., 2007). Det senaste decenniet har konceptet personlig återhämtning fått allt större genomslag på policynivå, ofta genom formulerade målsättningar om brukardelaktighet, personcentrerad vård och förmedling av hopp som en nyckelkomponent i stödet. Explicita ambitioner att organisera och förmedla stöd enligt principer om personlig återhämtning har uttryckts i länder som Australien, Nya Zeeland, Storbritannien och USA. I de nordiska länderna har inte principerna uttalats lika tydligt, men referenser finns i till exempel nationella riktlinjer och regionala dokument för verksamhetsutveckling (Bejerholm \& Roe, 2018; Fjellfeldt, Rosenberg \& Markström, 2017).

På vilket sätt kan då den idéutvecklingen inverka på det samhällsbaserade stöd som faktiskt förmedlas? Ett svar är att konceptet skulle kunna ge en principiell vägledning av hur man kan utforma och förmedla stöd i samhället, som ligger i linje med demokratiska principer och den värdegrund som artikuleras inom de flesta välfärdsorganisationer. Det handlar om att göra den enskilde delaktig och om att utforma ett system som underlättar för individuella lösningar och flexibilitet. Principerna om återhämtning kan ses som ett demokratiargument - de är i sig själva värda att beakta. Ett annat svar är att konceptet vuxit fram i samspel med forskningen. Den senare metodutvecklingen av samhällsbaserat stöd har utan tvivel influerats av idéerna om återhämtning samtidigt som konceptet i sin tur byggts ut och justerats genom nya forskningsresultat. Flera etablerade arbetssätt med starkt kunskapsstöd bygger på individualisering, delaktighet och inflytande, integrering av sociala och psykiatriska insatser samt en fältbaserad och uppsökande ansats - komponenter som är nära associerade med personlig återhämtning. Det kan ses som ett effektivitetsargument för att upprätthålla dynamiken mellan vägledande idéer och konkret verksamhets- och metodutveckling. 


\section{Metodutveckling}

I följande avsnitt beskrivs och kommenteras ett exempel på metodutveckling. Syftet är att illustrera hur en modell inom samhällsbaserat stöd till målgruppen kan vara utformad och hur en konstruktiv dynamik mellan forskning och verksamhetsutveckling kan se ut. Exemplet stöd till arbete genom individual placement and support (IPS) har valts därför att modellen dels visar på vetenskapliga landvinningar gjorda under den "postavinstitutionaliserade" eran (Markström \& Lindqvist, 2015), dels därför att den också kan illustrera de stora utmaningarna vid en lokal implementering, något som beskrivs i nästa avsnitt.

Länge fanns en utbredd pessimism när det gäller möjligheter till återhämtning och samhällsintegrering för personer med psykisk funktionsnedsättning. Det gällde inte minst synen på målgruppens plats på arbetsmarknaden. En barriär har utgjorts av negativa föreställningar om och förväntningar på gruppen, vilket har bidragit till svårigheter att hitta arbetsgivare som vill anställa. En annan barriär har varit välfärdsaktörernas bristande vilja och repertoar av insatser för att ge aktivt arbetsrehabiliterande stöd (Leff \& Warner, 2006). I Sverige beskrevs till exempel i psykiatriutredningens slutbetänkande hur unga personer med psykiatriska diagnoser ofta förtidspensionerades utan att ha blivit erbjudna några aktiva rehabiliteringsinsatser (SOU 1992:73).

IPS-modellen har visat på hur förenklade de gamla föreställningarna varit. Modellen utvecklades i USA av Deborah Becker och Robert Drake och har genom ett stort antal forskningsstudier kommit att betraktas som en evidensbaserad version av det något bredare konceptet supported employment (Bejerholm \& Roe, 2018). Modellen utformades specifikt för personer med långvarig och allvarlig psykisk ohälsa. Inom IPS tillämpas en så kallad place-then-train-ansats, vilket innebär att man först identifierar en arbetsplats där stödet utformas i stället för att inleda insatsen genom att individen får träna i en arrangerad och skyddad miljö. Arbetet utförs av en så kallad arbetsspecialist och guidas med hjälp av åtta principer:

1. Den enskildes önskemål om att arbeta startar insatsen. Det krävs ingen prövning av om personen är "anställningsbar" eller inte.

2. Insatsen utgår från klientens intressen, resurser och behov.

3. Målet är ett konkurrensutsatt arbete. Arbetet bör inte föregås av träning enligt en trappstegsmodell med successiv utslussning.

4.IPS-stödet ska vara nära samordnat och helst integrerat med psykiatrins insatser.

5. Processen med att kontakta arbetsgivare och hitta en matchning mellan individens intressen och befintliga arbetsplatser bör inledas tidigt, helst inom en månad efter det att individen uttryckt önskan om anställning. 
6. Stödet ska inte vara begränsat till en viss tidsperiod eller ha en uttalad deadline utan ges så länge behov finns.

7.Klienterna ska erbjudas ekonomisk vägledning och konsultation, exempelvis kring vilka regler och riktlinjer som är aktuella för sjukersättning och bostadstillägg.

8. Arbetsspecialisten bör skapa breda nätverk med arbetsgivare och upprätthålla en kontinuerlig kontakt med dem för att kunna ge stöd och för att kunna identifiera lämpliga arbetsmiljöer (Bond \& Drake, 2014; Markström \& Bejerholm, 2015).

\section{Lönearbete är möjligt}

Under tiden som IPS praktiserats och vetenskapligt studerats har principerna både reviderats och preciserats. Med hjälp av ett standardiserat underlag som består av 25 frågeområden är det möjligt att bedöma i vilken utsträckning en verksamhet följer de grundläggande principerna. Programtrohet har i flera studier visat sig ha betydelse för hur stor andel av klienterna som erhåller ett lönearbete (Bond, Becker \& Drake, 2011). Som alltid när det gäller välstuderade men komplexa interventioner finns varierande resultat och en variation i hur modellen har implementerats och tilllämpats. IPS ska inte ses som ett universalmedel mot arbetslöshet hos målgruppen - de flesta studier visar på perioder av arbetslöshet även under tiden med ett aktivt stöd. En stor majoritet av klienterna har också kvar en stor del av sin försörjning via sjukförsäkringssystemet. De anställningar som målgruppen får omfattar sällan heltid (Markström \& Bejerholm, 2015).

Om man bortser från de erfarenheter som beskrivs ovan, finns i dag övertygande vetenskapligt stöd för att IPS, i jämförelse med tillgängliga alternativ, är en effektiv strategi för att stödja personer till lönearbete. Det finns ett stort antal välgjorda effektstudier från olika delar av världen och flera systematiska kunskapsöversikter om arbetssättet. I en översikt från 2016 visade författarna att IPS var mer än dubbelt så effektiv i jämförelse med traditionell arbetsrehabilitering, vilket ofta innebar att mer än hälften av klienterna fått anställning vid uppföljningstiden (Modini et al., 2016). De här resultaten ligger i linje med tidigare sammanställningar (t.ex. Bond, Drake \& Becker, 2012). För utfall som inte är relaterade till anställning och inkomst är resultaten mer osäkra, men här finns studier som visar på minskat vårdutnyttjande och ökad upplevelse av egenmakt och livskvalitet (Drake, Bond \& Becker, 2013). Det vetenskapliga stödet för IPS som en väg till arbete och anställning har fått genomslag hos svenska myndigheter och inom ramen för det som benämns statlig kunskapsstyrning (Socialstyrelsen, 2015). I Socialstyrelsens riktlinjer för vård och stöd vid schizofreni (2018) ges IPS högsta prioritet, och SBU lyfter även upp modellens positiva effekter i en aktuell kommentar (SBU, 2018).

Sammanfattningsvis har IPS som modell kommit att ses som något av en gold 
standard för samhällsbaserat stöd till personer med psykisk funktionsnedsättning. Modellen har formats i en nära interaktion mellan innovativt utvecklingsarbete och forskning och kan i dag praktiseras med stöd av både guidande principer och detaljerade manualer för programtrohet. Arbetssättet innehåller en rad komponenter som inryms i konceptet personlig återhämtning. Dessutom stöds IPS av den svenska policynivån. Exemplet kan visa på räckvidden av den metod- och idéutveckling som skett på det avinstitutionaliserade psykiatriområdet de senaste decennierna, och på de möjligheter som ligger i en dynamik mellan praktik, forskning och policynivå. Följande avsnitt berör den kanske största utmaningen $i$ att realisera reformeringsarbetets intentioner, nämligen att konkret implementera kunskapsbaserade arbetssätt i det svenska vård- och stödsystemet.

\section{Implementeringsproblemet}

Utmaningen med att praktiskt tillämpa kunskapsbaserade arbetssätt i en nationell eller lokal kontext är beskriven sedan lång tid och har utgjort grunden för ett eget forskningsområde. Traditionen brukar benämnas implementation science och karaktäriseras av en ansats att mejsla fram centrala komponenter för en framgångsrik implementering. Enligt den logiken räcker det inte att en enskild arbetsmetod har visat sig effektiv i vetenskapliga försök och utvärderingar. Den behöver också införas på ett sätt som gör hög programtrohet och långsiktig etablering möjlig. För psykiatriområdet har den kritiska frågan om implementeringsgapet länge haft relevans. Vi vet att en liten andel av klienterna erbjuds en insats som baseras på bästa tillgängliga kunskap (Stirman et al., 2016). Sverige är ett av de länder som det senaste decenniet exponerats för ett stort antal nya modeller och program på området. Vanligtvis har de utformats och utvärderats i en anglosaxisk kontext. Denna import ställer krav på ett aktivt översättningsarbete, vilket har visat sig vara svårt. Delar av programmens ingredienser riskerar att förloras på vägen, vilket bedömts som problematiskt. Forskning om de här processerna har dock även betonat vikten av korrigeringar och lokala anpassningar för att kunna förankra nya arbetssätt och få nödvändig lokal legitimitet. Ytterst handlar det om att matcha modellens egenskaper med det nationella välfärdssystem som är aktuellt samt identifierade behov på den lokala nivån (Durlak \& DuPre, 2008).

\section{Etableringen av IPS}

Försöken att införa IPS som modell har i Sverige präglats av diskussioner om den över huvud taget är möjlig att implementera i ett sektoriserat system där ansvarsgränserna mellan kommuner och hälso- och sjukvård är så tydliga. IPS bygger på strategin att integrera stödet till arbete med den psykiatriska behandlingen - något som i en strikt mening skulle kräva att de båda huvudmännens ansvarsområden kan smälta samman. 
I praktiken har välfärdsaktörerna ofta riktat stödet till en bred grupp av personer med psykisk ohälsa eller funktionsnedsättning och tillämpat en bredare ansats av supported employment, utan krav på integrering av insatser (Bergmark, 2018; Hasson, Andersson \& Bejerholm, 2011; Nygren, 2012). Verksamheterna har vanligtvis organiserats inom Arbetsförmedlingen eller inom kommunernas arbetsmarknadsenheter. I en undersökning av två kommunala verksamheter i norra Sverige gavs insatser som delvis stämde överens med IPS-modellen och som visade på cirka 40 procent av klienterna i arbete eller studier efter ett år. Resultaten förbättrades ytterligare efter två år (Nygren et al., 2011; Markström, Nygren \& Sandlund, 2011). I Skåne genomfördes den enda randomiserade kontrollerade studien hittills av IPS, vilken visade på 46 procent av klienterna i anställning efter ett år (Bejerholm et al., 2015). Insatserna förmedlades här av en arbetsspecialist inom den öppna psykosvården, men gjordes inom ramen för ett experiment, varför insatsen upphörde när studien var genomförd. Studien kunde slå fast att goda utfall är möjliga i en svensk kontext men inte om en långsiktig etablering av modellen är möjlig (Hasson, Andersson \& Bejerholm, 2011). Exemplet illustrerar en spänning mellan experimentella effektstudier och in-real-lifeimplementation som även beskrivits i internationella studier om IPS (Liu, 2011).

\section{Vad gör långsiktig etablering möjlig?}

För att adressera implementeringsfrågan följde en svensk forskargrupp 14 orter som fått medel från Socialstyrelsen för att införa IPS. Pilotverksamheterna studerades under en treårsperiod genom programtrohetsskattningar, intervjuserier med personal och nyckelpersoner samt uppföljningar av klienter som fick insats. Det huvudsakliga syftet var att undersöka hur kommunerna lyckades med att implementera modellen och vilka specifika faktorer som hade betydelse för en etablering. Ett instrument togs fram och testades för att mäta viktiga komponenter i implementeringen. Instrumentet, sustainable implementation scale (SIS), utvecklades med utgångspunkt i ett antal forskningsöversikter om vad som har betydelse för en framgångsrik implementering av kunskapsbaserade metoder. I dem identifierades ett antal nyckelfaktorer som antogs ha betydelse för att införa IPS. Faktorerna delades in i fyra olika kategorier: system-, organisations- och teamnivå samt faktorer rörande fortlöpande stöd. De tre senare kategorierna antogs vara möjliga att operationalisera och arrangerades som tre delskalor (Markström et al., 2017; se tabell 1). Vid sidan om skalan gjordes även kvalitativa innehållsanalyser av det omfattande intervjumaterial som samlats in. 
Tabell 1. Valda kategorier*

\section{A. Systemnivå}

1. Det vetenskapliga stödet för modellen

2. Modellens tydlighet

3. Modellens anpassningsbarhet och flexibilitet

4. Politik och lagstiftning

5. Nationell policy på insatsområdet

6. Aktuella nationella satsningar på området

7. Föreställningar om målgruppen, attityder

B. Omständigheter på lokal organisatorisk nivå

1. Bedömningar och beskrivningar av behov som modellen kan tillgodose

2. Erfarenhet av liknande arbetssätt

3. Modellen uppfattas som legitim och i linje med organisationens värderingar

4. Finns en plats för modellen i organisationen, anpassningsbarhet

5. Implementeringsklimat

6. Samarbetskultur, erfarenhet av samverkan

7. Förankring hos opinionsledare och beslutsfattare

8. Tillgång till experter (eller champions) på ledningsnivå

9. Tillgång till extern expertis eller champions

10. Politiska beslut och strategier för lokal finansiering

11. En medvetet sammansatt och kompetent ledningsgrupp som följer satsningen

12. Samarbetspartners som stödjer satsningen

\section{Omständigheter på utförarnivå}

1. Medveten rekrytering och sammansättning av personalgruppen

2. Utbildning och träning i modellen

3. Närvarande ledare som tror på modellen

4. Samarbetspartners som underlättar klientarbetet

5. Informationsinsatser för att öka kunskapen om modellen

6. Återföring av erfarenheter och resultat till beslutsfattare

7. Kontinuitet vad gäller personal och chefer

\section{Fortlöpande strategier för stöd}

1. Fortbildning till personalen

2. Fortlöpande handledning och/eller konsultation i modellen

3. Återkommande programtrohetsskattningar

4. Tid för utrymme för reflektion och utvärdering

5. Tekniskt och administrativt stöd

*Kategorierna och de specifika faktorerna är hämtade från Damschroder et al., 2009; Durlak \& DuPre, 2008; Fixsen et al., 2005; 2009; Greenhalgh et al., 2004; Meyers, Durlak \& Wandersman, 2012. Listan finns även presenterad i Markström et al., 2015, och Markström et al., 2017. 
Resultaten från den longitudinella studien visade att SIS och de framtagna nyckelkomponenterna kunde predicera överlevnad av pilotverksamheterna (Bergmark, Bejerholm \& Markström, 2019). Efter tre år hade sex av de inkluderade IPSverksamheterna etablerats som en ordinarie del av kommunens organisation. Tre verksamheter hade efter samma uppföljningsperiod delvis infört IPS-principer, men saknade en organisatorisk stabilitet. Övriga fem hade lagts ned. Analyserna visade på en statistiskt signifikant skillnad i programtrohet efter ett och två år, där de etablerade verksamheterna uppvisade högre trohet gentemot IPS-principerna än de övriga. Det fanns också en signifikant skillnad i fråga om komponenterna i SIS. De etablerade verksamheterna hade efter ett år fler nyckelkomponenter på plats i jämförelse med övriga (Bergmark, Bejerholm, \& Markström, 2019; Markström et al., 2017).

Vad var det då som verkade ha betydelse för en etablering av IPS? Konkreta omständigheter som identifierades både i analyserna av SIS och i intervjuerna var noggrann rekrytering av personal och att erbjuda utbildning i den aktuella arbetsmetoden. Kontinuitet i personalgruppen samt engagemang och närvaro hos den närmsta chefen var betydelsefullt liksom en nära kontakt med samarbetspartners, $i$ det här fallet främst landstingens psykiatriska verksamhet. När det gäller aspekter av fortlöpande stöd återfanns komponenter som handledning och fortbildning samt utrymme för personalen att aktivt diskutera frågor relaterade till arbetsmetoden (Bergmark, Bejerholm \& Markström, 2018; 2019). Dessa faktorer kännetecknas av att $\mathrm{i}$ hög utsträckning vara påverkningsbara och enligt bland andra Meyers och kollegor (2012) och Fixen och kollegor (2009) kan de även fungera kompensatoriskt i meningen att ett underskott $i$ en del, som till exempel tillgång till kvalificerad personal, kan balanseras genom ett överskott $i$ en annan, som exempelvis internutbildning och handledning.

Särskilt kritiska komponenter identifierades på organisationsnivå. Flera av dem rör omständigheter i samband med planering och förberedelser inför organisationsförändringar eller andra satsningar. I det här aktuella fallet handlar det alltså om saker som behöver finnas på plats innan själva IPS-insatsen erbjuds klienterna (jfr Meyers et al., 2012). Några sådana komponenter som identifierades var att det fanns en bedömning av de lokala behoven att införa det nya arbetssättet, att det fanns en långsiktig finansieringsplan, att det fanns en inomorganisatorisk legitimitet för satsningen och att utvecklingsarbetet kunde drivas med hjälp av en noggrant sammansatt styroch implementeringsgrupp. Därutöver visade sig tillgång till experter på den aktuella arbetsmetoden vara viktigt (Bergmark, Bejerholm \& Markström, 2018; 2019).

Sammantaget visade resultaten från forskningsprojektet på möjligheterna att faktiskt införa och etablera IPS med hög programtrohet i det svenska vård- och stödsystemet. Vissa av de vägledande principerna, som att integrera stöd till anställning med psykiatrisk behandling, visade sig svåra att följa men de kunde i viss mån kompen- 
seras genom tätt lokalt samarbete mellan huvudmännen. Studien visade på vikten av förankring och noggranna förberedelser när nya arbetssätt ska implementeras. Studien kan också illustrera en av de mest angelägna utmaningarna för ett verksamhets- och insatsområde i en senare utvecklingsfas - där vägledande idéer och effektiva arbetssätt finns på plats, men där den slutliga översättningen till lokal vardagspraktik inte funnit sina former. Man bör notera att studien inte studerade den påverkan som omgivningsfaktorer och förhållanden på systemnivå kan ha på implementeringen, som till exempel karaktären på det svenska välfärdssystemet. Här finns forskning som uppmärksammat faktorer som till exempel policyutformning, karaktären på det organisatoriska landskapet, strategier för styrning, professioners handlingsutrymme och intressegruppers agerande (Johansson, 2010). De här omständigheterna behöver man ta hänsyn till i en heltäckande analys av etablerandet av nya verksamhetsområden eller arbetsmetoder.

\section{Avslutning: Ett moget verksamhetsfält?}

Artikeln har innehållit en beskrivning av och diskussion om framväxten av ett delvis nytt fält för samhällsbaserat psykosocialt stöd till personer med psykisk funktionsnedsättning. Det finns utan tvivel problem och missförhållanden i den vård och stöd som arrangeras för målgruppen - mycket tycks handla om otillräckliga och ineffektivt samordnade insatser. Samtidigt visar historiska jämförelser att fältet påtagligt förändrats där en rad kunskapsluckor krympt genom en kombination av verksamhetsutveckling och praktiknära forskning. Det finns i dag en kunskapsbas och en vårdideologisk medvetenhet om samhällsbaserat stöd som tidigare saknats. Jag har försökt exemplifiera det genom att diskutera konceptet personlig återhämtning och specifika kunskapsbaserade insatser som formats i samarbete mellan forskning och fält.

Personlig återhämtning bör inte ses som ett dogmatiskt koncept, eftersom det snarare tillämpats som en bred reflektionsyta för en mer positivt inriktad, personcentrerad och samhällsbaserad psykiatri (Bejerholm \& Roe, 2018). Tankeramen fokuserar den enskildes situation och erfarenhet, vilket i praktiken kan innebära en starkare orientering mot delat beslutsfattande och delaktighet i de insatser som ges. Erfarenheterna så här långt visar också på att ett återhämtningsinriktat stöd innebär minskat fokus på reduktion av symtom i behandlingen och större uppmärksamhet på sociala omständigheter (Bejerholm \& Roe, 2018). Man kan tolka konceptets plats på verksamhetsfältet som ett utslag av en tillfällig och övergående trend. Mer rimligt är emellertid att se personlig återhämtning som ett resultat av en långsiktig utveckling av organisationer och arbetssätt där grundelementen baseras på moderna föreställningar om demokrati och delaktighet samt på forskning om samhällsbaserade insatser. 
Idéer av ovanstående slag kan vara vägledande men är ofta inte tillräckliga för att åstadkomma varaktig förändring, som kräver förändringar av rutiner och konkreta arbetssätt. På 25 år har kunskapsbasen stärkts betydligt på området. När det svenska reformeringsarbetet tog fart på 1990-talet fanns få perspektiv och strategier att ta spjärn mot - i dag finns en uppsjö interventioner och ett internationellt forskningsfält om samhällsbaserade insatser (Bergmark, Bejerholm \& Markström, 2017; Jones et al., 2018; Socialstyrelsen, 2018). Med det inte sagt att mängden metoder med stark vetenskaplig evidens är överväldigande - det finns fortfarande grundläggande insatsområden för gruppen, som till exempel boende och boendestöd, där osäkerheten kring vad som är framgångsrika strategier fortfarande är påtaglig (McPherson, Krokofil \& Killaspy, 2018). Det centrala är dock att det finns intresse och att det läggs ner ansträngningar på att utveckla och diskutera stödets innehåll, och här är både den politiska nivån och förvaltningen inom kommunernas socialtjänst viktiga aktörer. Det finns studier som visar på otydlighet i fråga om ansvaret för en kunskapsbaserad socialtjänst mellan dessa nivåer, men också tecken på att intresset för frågorna ökar (Bäck et al., 2016; Socialstyrelsen, 2017b).

Vad jag särskilt velat styra uppmärksamheten mot i texten är betydelsen av att ta sig an implementeringsproblemet. Om forskning och verksamhetsutveckling på området samhällsbaserat stöd så här långt koncentrerat sig på att ta fram och pröva nya arbetssätt, behöver nu frågan om metodernas översättning och etablering $\mathrm{i}$ en nationell och lokal kontext uppmärksammas. Det bör både handla om hur modeller kan implementeras fullt ut i situationer där resurser i form av ekonomiska medel och kunskap är goda, och om hur man långsiktigt kan etablera och skapa legitimitet för kunskapsbaserade arbetssätt där resurser är knappa och där lokala anpassningar blir nödvändiga. Styrkan med forskning och utvecklingsarbete kring implementering är att frågorna till stor del är generella och delas av de flesta sektorer inom välfärdsområdet - det krävs ofta inte någon exklusiv implementeringsforskning om varje enskilt verksamhetsområde så länge de involverade organisationerna har egenskaper som man delar med andra välfärdsaktörer. I fallet med samhällsbaserat stöd till personer med psykisk funktionsnedsättning är frågor om ledarskap, utbildning och handledning, tvärprofessionellt arbete, flexibel organisering och tät samverkan med vårdgrannar viktiga faktorer att hantera i en implementeringsprocess. De finns som bekant i flera liknande verksamhetsfält. 


\section{Referenser}

Bejerholm, U., Areberg, C., Hofgren, C., Sandlund, M. \& Rinaldi, M. (2015) Individual placement and support in Sweden. A randomized controlled trial. Nordic Journal of Psychiatry, 69: 57-66.

Bejerholm, U. \& Roe, D. (2018) Personal recovery within positive psychiatry. Nordic Journal of Psychiatry, DOI: 10.1080/08039488.2018.1492015.

Bergmark, M. (2018) Integrerade psykosociala insatser. Policy, implementering och praktik i ett komplext verksamhetsfält. Akademisk avhandling. Umeå: Umeå universitet.

Bergmark, M., Bejerholm, U. \& Markström, U. (2017) Policy changes in community mental health. Interventions and strategies used in Sweden over 20 years. Social Policy \&. Administration, 51(1): 95-113.

Bergmark, M., Bejerholm, U. \& Markström, U. (2018) Critical components in implementing evidence-based practice. A multiple case study of individual placement and support for people with psychiatric disabilities. Social Policy \& Administration, 52(3): 790-808.

Bergmark, M., Bejerholm, U. \& Markström, U. (2019) Implementation of evidence-based interventions. Analyzing critical components for sustainability in community mental health services. Social Work in Mental Health, 17(2): 129-148.

Bond, G.R., Becker, D.R. \& Drake, R.E. (2011) Measurement of fidelity of implementation of evidence-based practices. Case example of the IPS fidelity scale. Clinical Psychology, 18: 126-141.

Bond, G.R., Drake, R.E. \& Becker, D.R. (2012) Generalizability of the individual placement and support model of supported employment outside the US. World Psychiatry, 11:32-39.

Bond, G.R. \& Drake, R.E. (2014) Making the case for IPS supported employment. Administration and Policy in Mental Health and Mental Health Services Research, 41: 69-73.

Bäck, A., Ståhl, C., von Thiele Schwarz, U., Richter, A. \& Hasson, H. (2016) Walking the tightrope. Perspectives on local politicians' role in implementing a national social care policy on evidence-based practice. International Journal of Mental Health Systems, 10(75), doi: 10.1186/ s13033-016-0107-1

Damschroder, J.L., Aron, D.C., Keith, R.E., Kirsh, S.R., Alexander, J.A. \& Lowery, J.C. (2009) Fostering implementation of health services research findings into practice. A consolidated framework for advancing implementation science. Implementation Science, 4:50.

Dir.2016:106. Tilläggsdirektiv till Nationell samordnare för utveckling och samordning av insatser inom området psykisk hälsa. Kommittédirektiv från Socialdepartementet.

Drake, R.E., Bond, G.R. \& Becker, D.R. (2013) Individual placement and support. An evidence-based approach to supported employment. New York: Oxford University Press.

Durlak, J. \& DuPre, E. (2008) Implementation matters. A review of research on the influence of implementation on program outcomes and the factors affecting implementation. American Journal of Community Psychology, 41: 327-350.

Fixsen, D.L., Naoom, S.F., Blas, K.A., Friedman, R.M. \& Wallace, F. (2005) Implementation research. A synthesis of the literature. Tampa, FL: University of South Florida, Louis de la Parte Florida Mental Health Institute, The National Implementation Research Network (FMHI Publication \#231).

Fixsen, D.L., Naoom, F., Blas, K.A., Friedman, R.M. \& Wallace, F. (2009) Core implementation components. Research on Social Work Practice, 19:531.

Fjellfeldt, M. \& Markström, U. (2018) Länsgemensamma insatser för psykisk hälsa. En balansakt. Umeå: Umeå universitet, Institutionen för socialt arbete. 


\section{Socialvetenskaplig tidskrift 2019:3-4}

Fjellfeldt, M., Rosenberg, D. \& Markström, U. (2017) Psykisk hälsa - ett mångfacetterat begrepp. Analys av behovsbilder och handlingsstrategier $i 21$ länsplaner sammanställda inom ramen för statens satsning inom området psykisk hälsa. Umeå: Umeå universitet, Institutionen för socialt arbete.

Greenhalgh, T., Robert, G., Macfarlane, F., Bate, P. \& Kyriakidou, O. (2004) Diffusion of innovations in service organisations. Systematic review and recommendations. The Milbank Quarterly, 82(4): 581-629.

Gureje, O. (2015) Public mental health. The need for a broader view of the issues. World Psychiatry, 14(1): 54-55.

Hasson, H., Andersson, M. \& Bejerholm, U. (2011) Barriers in implementation of evidence-based practice. Supported employment in Swedish context. Journal of Health and Organisational Management, 25: 332-345.

Jensen, C., Johansson, S. \& Löfström, M. (2017) Policy implementation in the era of accelerating projectification. Synthesizing Matland's conflict-ambiguity model and research on temporary organizations. Public Policy and Administration, 33(4): 447-465.

Johansson, S. (2010) Implementing evidence-based practices and programmes in the human services. Lessons from research in public administration. European Journal of Social Work, 13(1): 109-125.

Jones, A., Hannigan, B., Coffey, M. \& Simpson, A. (2018) Traditions of research in community mental health care planning and care coordination. A systematic meta-narrative review of the literature. PLoS ONE, 13(6): e0198427.

Leamy, M., Bird, V., LeBoutillier, C., Williams, J. \& Slade, M. (2011) Conceptual framework for personal recovery in mental health. Systematic review and narrative synthesis. British Journal of Psychiatry, 199: 445-452.

Leff, J. \& Warner, R. (2006) Social inclusion of people with mental illness. Cambridge: Cambridge University Press.

Leonhardt, B., Huling, K., Hamm, J., Roe, D., Hasson-Ohayon, I., McLeod, H.J. \& Lysaker, P.H. (2017) Recovery and serious mental illness. A review of current clinical and research paradigms and future directions. Expert Rev Neurother, 17: 1117-1130.

Lindqvist, R., Markström, U. \& Rosenberg, D. (2014) Psykiska funktionshinder i samhället. Aktörer, insatser, reformer. 2 uppl. Malmö: Gleerups.

Liu, H-H.N. (2011) Policy and practice. An analysis of the implementation of supported employment in Nebraska. Theses, Dissertations, and Student Research: Department of Psychology. Paper 30.

Markström, U. (2003) Den svenska psykiatrireformen. Bland brukare, eldsjälar och byråkrater. Akademisk avhandling. Umeå: Boréa förlag.

Markström, U. \& Bejerholm, U. (2015) Mot alla odds - stöd till arbete för personer med psykisk funktionsnedsättning. I: K. Ekberg, M. Eklund \& G. Hensing (red.) Återgång i arbete. Processer, bedömningar, åtgärder. Lund: Studentlitteratur.

Markström, U., Bejerholm, U., Svensson, B. \& Bergmark, M. (2015) Implementeringen av nationella riktlinjer för psykosociala insatser vid schizofreni. Exemplen IPS och ACT. CEPI och Umeå universitet. ISBN 978-91-7623-254-5.

Markström, U. \& Lindqvist, R. (2015) Establishment of community mental health systems in a post-deinstitutional era. A study of organisational structures and service provision in Sweden. Journal of Social Work in Disability and Rehabilitation, 14(2): 124-144.

Markström, U., Nygren, U. \& Sandlund, M. (2011) Arbete för alla? Införande och resultat av supported employment i en svensk kommun. CEPI och Socialpsykiatriskt Kunskapscentrum i Västerbotten. 
Markström, U., Svensson, B., Hansson, L., Bergmark, M. \& Bejerholm, U. (2017) What influences a sustainable implementation of evidence-based interventions in community mental health services? Development and pilot testing of a tool for mapping core components. Journal of Mental Health, doi: 10.1080/09638237.2017.1417544.

McPherson, P., Krotofil, J. \& Killaspy, H. (2018) Mental health supported accommodation services. A systematic review of mental health and psychosocial outcomes. BMC Psychiatry, 18:128, doi. org/10.1186/s12888-018-1725-8.

Mehta, N., Croudace, T. \& Davies, D. (2015) Public mental health. Evidence-based priorities. The Lancet, 385(9976): 1472-1475.

Meyers, D., Durlak, J. \& Wandersman, A. (2012) The quality implementation framework. A synthesis of critical steps in the implementation process. American Journal of Community Psychology, 50: 462-480.

Modini, M., Tan, L., Brinchmann, B., Wang, M.J., Killackey, E., Glozier, N., Mykletun, A. \& Harvey, S.B. (2016) Supported employment for people with severe mental illness. Systematic review and meta-analysis of the international evidence. British Journal of Psychiatry, 209: 14-22.

Nygren, U. (2012) Individual placement and support i en socialpsykiatrisk context. En väg till arbete för personer med psykiskt funktionshinder? Akademisk avhandling. Umeå: Umeå universitet.

Nygren, U., Markström, U., Svensson, B., Hansson, L. \& Sandlund, M. (2011) Individual placement and support for people with mental illness. The first Swedish report of outcomes. Scandinavian Journal of Caring Sciences, 25 (3): 591-598.

Onken, S., Craig, C., Ridgway, P., Ralph, R.O. \& Cook, J.A. (2007) An analysis of the definitions and elements of recovery. A review of the literature. Psychiatric Rehabilitation Journal, 31: 9-22.

Regeringskansliet och Sveriges Kommuner och Landsting (2016) Stöd till riktade insatser inom området psykisk hälsa 2017.

Richardson, K. \& Barkham, M. (2017) Recovery from depression. A systematic review of perceptions and associated factors. Journal of Mental Health, 6: 1-13. doi: 10.1080/09638237.2017.1370629.

SBU (2018) Arbetsfrämjande åtgärder för personer med funktionsnedsättning som söker arbete. Betydelsen av supported employment och individual placement and support. SBU kommenterar, juni 2018.

Schön, U.-K. (2009) Kvinnors och mäns återhämtning från psykisk ohälsa. Stockholm: Stockholm studies of social work 130 .

Socialstyrelsen (2003) Boende för personer med psykiska funktionshinder. En nationell uppföljning och utvärdering av boendeformer inom socialtjänsten. Stockholm: Socialstyrelsen.

Socialstyrelsen (2013a) Personer med funktionsnedsättning. Vård och omsorg den 1 oktober 2012. Artnr 2013-4-18.

Socialstyrelsen (2013b) Nationell utvärdering 2013. Vård och insatser vid depression, ångest och schizofreni. Artikelnummer 2013-6-7.

Socialstyrelsen (2015) Samordnad statlig kunskapsstyrning inom området psykisk ohälsa. Slutrapport av ett regeringsuppdrag. Artikelnummer 2015-12-9.

Socialstyrelsen (2017a) Sysselsättning för personer med psykisk funktionsnedsättning. Uppföljning av 2016 års verksamhetsbidrag. Artikelnummer 2017-5-17.

Socialstyrelsen (2017b) Evidensbaserad praktik i socialtjänsten 2007, 2010, 2013 och 2016. Stockholm: Socialstyrelsen.

Socialstyrelsen (2018) Nationella riktlinjer för vård och stöd vid schizofreni och schizofreniliknande tillstånd. Stöd för styrning och ledning. Artikelnummer 2018-9-6. 


\section{Socialvetenskaplig tidskrift 2019:3-4}

SOU 1992:73 Välfärd och valfrihet. Service, stöd och vård för psykiskt störda. Stockholm: Allmänna förlaget.

SOU 2006:100 Ambition och ansvar. Nationell strategi för utveckling av samhällets insatser till personer med psykiska funktionshinder. Slutbetänkande av Nationell Psykiatrisamordning.

SOU 2018:90 För att börja med något nytt måste man sluta med något gammalt. Slutbetänkande av nationell samordnare för utveckling och samordning av insatser inom området psykisk hälsa. Stockholm: Norstedts Juridik.

Stirman, S., Gutner, C., Langdon, K. \& Graham, J. (2016) Bridging the gap between research and practice in mental health service settings. An overview of developments in implementation theory and research. Behaviour Theraphy, 47(6): 920-936.

Thomas, E., Despeaux, K., Drapalski, A. \& Bennett, M. (2018) Person-oriented recovery of individuals with serious mental illnesses. A review and meta-analysis of longitudinal findings. Psychiatric Services, 69: 259-267.

Thornicroft, G., Semrau, M., Alem, A., Drake, R.E., Ito, H., Mari, J., McGeorge, P. \& Thara, R. (2011) Community mental health. Putting policy into practice globally. Singapore: Wiley-Blackwell.

Topor, A. (2001) Managing the contradictions. Recovery from severe mental disorders. Stockholm: Stockholm studies of social work 18.

Uppdrag psykisk hälsa (2017) Psykiatrin i siffror. Vuxenpsykiatrin - kartläggning 2017.

Vårdanalys (2015) Psykisk hälsa. Ett gemensamt ansvar. Lärdomar från PRIO och tidigare statliga satsningar sedan 1995. Rapport 2015:10.

Wahlbeck, K. (2015) Public mental health. The time is ripe for translating of evidence into practice. World Psychiatry, 14(1):36-42. 